\title{
Study on digestive tract contents of fish : Preliminary step for identification of indigenous species in mosquito larval control
}

\author{
N. Pemola Devi ${ }^{1}$ and R. K. Jauhari* \\ Parasitology Laboratory, Department of Zoology, D.A.V. (P.G.) College, Dehradun, INDIA \\ ${ }^{1}$ Department of Zoology, D.B.S. (P.G.) College, Dehradun, INDIA \\ *Corresponding author. E-mail: jauharirk@ hotmail.com
}

\begin{abstract}
The present study is based on screening of food preference by the indigenous fish under its natural condition. The gastrointestinal contents as an indicative of effective bioregulatory activity envisage the selection of a larvivorous fish. As many as 32 species of fishes were collected from their natural habitats at Imphal and Bishenpur districts in Manipur State between August 2007 to February 2008. Faecal drops of active fishes revealed remains of larvae / pupae of mosquitoes. However, the food types in 26 species of fish comprised larvae / pupae of mosquito, algae, weeds, tadepole fishes, crustaceans, insects, gastropods, worms and detritus / debris. On the basis of food preference Aplocheilus panchax, Polyacanthus fasciatus and Puntius manipurensis have been considered as most potent larvivorous fish of the study area.
\end{abstract}

Keywords : Larvivorous fish, Mosquito control, Digestive tract, Manipur

\section{INTRODUCTION}

The biological control of mosquito vectors using larvivorous fish plays an increasingly important role in integrated management strategies, particularly in urban and per urban areas (Gratz and Pal, 1988). It is usually based on establishing a predator population in the mosquito-infested water body. This method effectively restricts the use of fish to permanent water bodies of relatively high water quality which enables the natural propagation of the predator population. For several decades, different species of fish have been used in biological control of mosquito larvae, especially in natural breeding sites (Gerberich and Laird, 1968; Bence, 1988; Nelson and Keenan, 1992; Fletcher et al., 1993; Torrente et al., 1993; Lee, 2000; Hurst et al., 2004 and Rehage et al., 2005).

The larvivorosity of a fish can be tested depending on the consumption of mosquito larvae alone or along with alternative food under natural conditions. In fact, prior to investígate the feeding potential of a particular fish species towards mosquito immature, it is necessary to identify its feeding habits in natural conditions. This leads to food preferences by the selected species of fish. Hence, the gastrointestinal contents of the fish are indicative of its effective bioregulatory activity and on this basis the fish is to be considered as larvivorous.

Manna et al. (2008) experimentally shown that the regulation of the mosquito immature by the natural predators is affected by the presence of alternative prey; however, the prey consumption ability of the larvivorous fish increases with the body size in Peocilia reticulata as evidenced by their studies showing low preference for the $C x$. quinquefasciatus larvae as compared to the chironomid larvae and tubificid worms, when all the three prey types were present. Earlier, Rojas et al. (2005) presented characteristics and selection of a larvivorous fish based on the contents of digestive tract and a conclusive interpretation towards an effective bioregulatory activity of the fish under natural conditions. In India, though a considerable amount of work on larvivorous fish and their larvivorosity tests has been carried out (Sharma and Ghosh, 1989; Das and Prasad, 1991; Jauhari et al., 1996; Haq and Yadav, 2003; Ghosh et al., 2006; Chandra et al., 2008) but still there are scattered reports on the effective bioregulatory activity of fish to be considered it as potent larvivore. Moreover, our knowledge on such aspects is meager in general and in particular from Manipur state and henceforth, an investigation is being made to identify an indigenous species of fish that could witness its role in larval mosquito control.

\section{MATERIALS AND METHODS}

Study site: For Ichthyo-faunal diversity in Manipur state, at the initial stage the water bodies existing in the vicinity of the following 2 districts viz., Imphal and 
Bishenpur were surveyed during August 2007 to February 2008. In the district Imphal, the fishes were sampled from rivers and ponds while from Bishenpur district, it was from rice fields, water fed low lying areas, rocky streams and Loktak lake.

Collection of fish and analysis of gastrointestinal contents : Fish were collected from their natural habitats by using locally employed fishing nets and then transported to the laboratory in a plastic bucket (10 1 capacity) containing water from the collection site and aerated by a battery - operated portable air pump. Collected fishes were grouped into two categiroes - more active and less one. The active fishes were transfered to aquaria for analyzing their faecal drops in subsequent days. The faecal matter was collected by pipette and placed on a slide. Excess water was removed with filter paper, then added a drop of glycerine and, thereafter, examined under a zoom stereo trinocular for presence of mosquito larval remains viz., head, hair, cuticles, etc.

Fishes were identified using relevant literature (Vishwanath et al., 2007) and total length of each individual was measured. Selected fish was eviscerated and the stomach contents were scooped out. Food items were identified as much as possible. Whenever required the collected items were preserved in $4 \%$ formaldehyde solution for taxonomical identification.

\section{RESULTS}

The fish faunal diversity of selected areas of Manipur state during the study period revealed 32 species of

Table 1. List of fishes collected from different habitats of the selected area in Manipur state during August 2007 - February 2008.

\begin{tabular}{|c|c|c|c|c|c|c|}
\hline \multirow{2}{*}{$\begin{array}{l}\text { SI. } \\
\text { No. }\end{array}$} & \multirow[t]{2}{*}{ Name of species } & \multicolumn{5}{|c|}{ Habitats } \\
\hline & & River & Lake & Pond & Rice field & Stream \\
\hline 1 & Barilius bendelisis (Hamilton) & + & + & + & - & - \\
\hline 2 & B. ngawa Vishwanath \& Manojkumar & + & + & + & - & - \\
\hline 3 & Esomus danricus (Hamilton) & + & + & + & + & - \\
\hline 4 & Danio rerio (Hamilton) & - & + & - & + & + \\
\hline 5 & Rasbora daniconius (Hamilton) & + & + & + & - & + \\
\hline 6 & Amblypharyngodon mola (Hamilton) & + & + & + & & - \\
\hline 7 & Puntius chola (Hamilton) & + & + & + & + & + \\
\hline 8 & P. sophore (Hamilton) & + & + & + & + & - \\
\hline 9 & P. ticto (Hamilton) & + & + & + & + & - \\
\hline 10 & P. manipurensis Menon, Rema Devi \& Vishwanath & + & + & - & - & + \\
\hline 11 & P. jayarami Vishwanath \& Tombi & + & + & - & + & + \\
\hline 12 & Mystus cavasius (Hamilton) & + & + & + & - & + \\
\hline 13 & M. vittatus (Bloch) & + & + & + & - & + \\
\hline 14 & Clarius batrachus (Linnaeus) & + & + & + & - & + \\
\hline 15 & C. gariepinus (Burchell) & + & + & - & - & + \\
\hline 16 & Heteropnuestes fossilis (Bloch) & + & + & + & - & + \\
\hline 17 & Aplocheilus panchax (Hamilton) & & + & - & - & - \\
\hline 18 & Chanda nama Hamilton & + & + & + & + & + \\
\hline 19 & Glossogobius giuris (Hamilton) & + & + & + & + & - \\
\hline 20 & Anabas testudineus (Bloch) & + & + & + & + & - \\
\hline 21 & Channa striata (Bloch) & + & + & + & + & + \\
\hline 22 & C. punctatus (Bloch) & + & + & + & - & + \\
\hline 23 & C. gachua (Hamilton) & + & + & - & - & - \\
\hline 24 & Polyacanthus fasciatus (Bloch \& Schneider) & + & + & + & - & + \\
\hline 25 & P. sota (Hamilton) & + & + & + & + & + \\
\hline 26 & Labeo rohita (Hamilton) & + & + & + & - & - \\
\hline 27 & L. calbasu (Hamilton) & + & + & + & - & - \\
\hline 28 & Catla catla (Hamilton) & + & + & + & - & - \\
\hline 29 & Cirrhinus mrigala (Hamilton) & + & + & + & - & - \\
\hline 30 & C. reba (Hamilton) & + & + & + & - & - \\
\hline 31 & Osteobrama cotio (Hamilton) & + & + & - & - & + \\
\hline 32 & Wallogo attu (Schneider) & - & + & - & - & + \\
\hline
\end{tabular}

Note: $+=$ Present $;-$ = Absent 
fishes, representing 11 families (Table 1). Out of these, 26 species were common while remaining 06 species were rare. In all, 575 specimens of fishes were collected and grouped into 3 categories based on vertical distribution viz., typical surface feeder (Aplochelius panchax); subsurface feeder (Amblypharyngodon mola, Danio rerio, Rasbora daniconius and Esomus danricus) and column feeder (Puntius chola, P. sophore, P. ticto, P. manipurensis, $P$. jayarami, Polyacanthus fasciatus, $P$. sota, Chanda nama, Barilius bendelisis, B. ngawa and Anabas testudineus; fry of craps - Labeo rohita, $L$. calbasu, Catla catla, Cirrhinus mrigala and C. reba).
Some immature forms of predatory fishes like Channa punctatus, C. striata, Clarias batrachus, Clarias gariepinus, Mystus cavasius, M. vittatus and Glossogobius giuris were also collected during the survey work. In general, the diversity was recorded more in the lake followed by rivers, ponds, streams and rice fields.

While examining the faecal drops, there was a major portion of remains of larvae and pupae mosquitoes in the aquarium water where Aplocheilus panchax was kept, followed by Polyacanthus fasciatus, Anabas testudineus and Mystus cavasius in succeeding order. Faecal remains of some fishes like Glossogobius giuris, Channa

Table 2. Details of food contents* in the gut of selected fishes collected from water bodies of district Imphal and Bishenpur in Manipur state.

\begin{tabular}{|c|c|c|c|c|c|c|c|c|c|}
\hline Food Type & Algae & Weeds & $\begin{array}{l}\text { Tadepole } \\
\text { fish }\end{array}$ & $\begin{array}{l}\text { Larvae/ } \\
\text { Pupae }\end{array}$ & Crustacean & Insects & Gastropods & Worms & $\overline{\text { Others }}$ \\
\hline Barilius bendelisis & 33.3 & 50.0 & 0 & 41.6 & 0 & 16.6 & 0 & 8.3 & 33.3 \\
\hline Esomus danricus & 28.0 & 20.0 & 0 & 58.0 & 0 & 20.0 & 0 & 32.0 & 12.0 \\
\hline Rasbora daniconius & 30.0 & 40.0 & 0 & 60.0 & 20.0 & 30.0 & 0 & 20.0 & 20.0 \\
\hline $\begin{array}{l}\text { Amblypharyngodon } \\
\text { mola }\end{array}$ & 11.1 & 0 & 0 & 55.5 & 0 & 44.4 & 0 & 29.6 & 0 \\
\hline Puntius chola & 8.5 & 12.5 & 0 & 47.8 & 2.7 & 52.3 & 0 & 17.2 & 3.5 \\
\hline P. sophore & 12.5 & 21.3 & 0 & 40.5 & 0 & 48.7 & 0 & 22.1 & 5.7 \\
\hline P. ticto & 13.7 & 15.2 & 5.3 & 57.9 & 5.3 & 51.9 & 2.2 & 15.7 & 1.5 \\
\hline P. manipurensis & 10.3 & 11.7 & 0 & 62.3 & 7.3 & 42.8 & 0 & 32.5 & 5.6 \\
\hline Mystus cavasius & 12.5 & 20.0 & 17.5 & 27.5 & 37.5 & 67.5 & 42.5 & 52.5 & 92.5 \\
\hline M. vittatus & 10.5 & 15.3 & 5.7 & 20.3 & 11.7 & 37.4 & 20.3 & 42.8 & 53.2 \\
\hline Clarius batrachus & 10.3 & 5.7 & 12.8 & 43.5 & 11.8 & 23.7 & 15.8 & 52.7 & 47.5 \\
\hline C. gariepinus & 20.7 & 10.2 & 21.7 & 40.7 & 15.8 & 27.9 & 20.3 & 48.5 & 68.5 \\
\hline $\begin{array}{l}\text { Heteropnиеstes } \\
\text { fossilis }\end{array}$ & 5.2 & 8.7 & 10.3 & 15.7 & 7.2 & 37.4 & 11.3 & 42.7 & 57.2 \\
\hline Aplocheilus panchax & 14.5 & 8.1 & 0 & 76.3 & 24.5 & 44.2 & 0 & 45.9 & 0 \\
\hline Chanda nama & 8.1 & 18.9 & 0 & 21.6 & 5.4 & 32.4 & 0 & 29.7 & 8.1 \\
\hline Glossogobius giuris & 22.7 & 20.5 & 0 & 32.5 & 7.2 & 43.8 & 0 & 77.2 & 23.8 \\
\hline Anabas testudineus & 9.5 & 9.5 & 14.2 & 14.2 & 9.5 & 9.5 & 23.8 & 71.1 & 28.5 \\
\hline Channa striata & 16.6 & 19.0 & 47.6 & 35.7 & 30.9 & 52.3 & 35.7 & 64.2 & 11.9 \\
\hline C. punctatus & 18.5 & 22.9 & 62.8 & 29.7 & 40.2 & 33.9 & 20.8 & 37.4 & 15.2 \\
\hline $\begin{array}{l}\text { Polyacanthus } \\
\text { fasciatus }\end{array}$ & 11.7 & 10.5 & 2.8 & 67.3 & 13.7 & 39.7 & 15.7 & 48.2 & 18.3 \\
\hline P. sota & 13.1 & 7.8 & 5.2 & 65.4 & 28.9 & 26.3 & 13.1 & 31.5 & 5.2 \\
\hline Labeo rohita & 18.7 & 6.25 & 0 & 50.2 & 0 & 43.7 & 0 & 31.2 & 0 \\
\hline L. calbasu & 24.5 & 12.2 & 0 & 47.2 & 0 & 36.7 & 0 & 22.3 & 0 \\
\hline Catla catla & 10.2 & 22.4 & 0 & 36.7 & 0 & 33.4 & 0 & 21.2 & 5.7 \\
\hline Cirrhinus mrigala & 10.5 & 20.5 & 0 & 47.7 & 0 & 53.2 & 0 & 11.5 & 5.5 \\
\hline C. reba & 1.7 & 6.5 & 0 & 51.2 & 0 & 74.7 & 0 & 34.2 & 0 \\
\hline
\end{tabular}

* The figure for each food type indicates the percentage of fish specimens harbouring that particular food 
punctatus and Clarias batrachus composed of mostly algae, tadepole fishes, debris and worms.

Table 2 represents the details about the food types examined under the microscope in all the 26 species of fishes, categorised into 2 groups. The first group was of active fishes comprising 14 species as marked with an asterisk while remaining fishes were inactive i.e., the live specimens could not be obtained. The food ítems as available in the digestive tract of the dissected fishes, comprised the larvae and pupae of mosquitoes, algae, weeds, tadepole fishes, crustaceans, insects, gastropods, worms and detritus/debris.

It is recorded that the larvae/pupae of mosquito constituted major part of food items in Aplocheilus panchax, Polyacanthus fasciatus, Polyacanthus sota, Puntius manipurensis, Rasbora daniconius and Esomus danricus while major portion of vegetation part was recovered in specimens of Barilius bendelisis, Rasbora daniconius and Esomus danricus. In the fishes like, Anabas testudineus, Glossogobius giuris, Channa straita, Clarias batrachus and Mystus cavasius the major part of food items belonged to worms. The detritus was present in most of the specimens of Mystus cavasius, Clarias gariepinus and Heteropneustus fossilis, followed by insects and worms remains. The percentage of gastropod snail was recorded more in the active fish than the inactive ones. Further, maximum specimens of Channa punctatus, C. striata and Clarias gariepinus consisted tadepole fish in their stomach contents as the major part of food.

Based on the dietary food items as recorded in the stomach of the fish, the following 8 species of fish viz., A. panchax, Polyacanthus fasciatus, P. sota, Puntius ticto, $P$. manipurensis, Amblyparyngodon mola, E. danricus and Rasbora daniconius were taken into consideration for larvivorosity purpose. Gastro-intestinal analysis of all the selected fishes showing remains of larval/pupae of mosquitoes as compared to other items have been depicted in Fig. 1. In almost all the 8 selected fishes, the larvae/ pupae of mosquito along with alternative food constituted major part of diet. However, in A. panchax the gastrointestinal contents reveal high preference of larvae/ pupae of mosquito with other alternative food as compared to only larvae/pupae or other elements. In the fishes like, Puntius manipurensis, P. ticto, Polyacanthus fasciatus, $P$. sota and Esomus danricus there was high preference towards mosquito larvae/pupae along with other alternative food. As compared to only other elements i.e., debris / detritus, the fish Amblypharyngodon mola was on the first rank and next to it there were Polyacanthus sota, E. danricus and Polyacanthus fasciatus in succession.

\section{DISCUSSION}

The findings of the present study reveal a difference in the percentage of food items collected as a result of evisceration of stomach. This study exhibit that most of the selected fishes feed more on mosquito larvae in presence of alternative food. Comparatively, there was less percentage of fishes where mosquito larvae and pupae were present alone. According to Reddy and Shakuntala (1979) when mosquito larvae alone were offered in terms of numbers, the fish Gambusia affinis predated more; however, its preference to feed on larvae is reduced when larvae are supplemented with Tubifex tubifex. Further, feeding on mosquito larvae by G. affinis and Poecilia reticulata is reduced in presence of oligochaete worms. As per views of Jacob and Nair (2006), the dipteran larvae are preferred items of diet of Aplocheilus lineatus in all size groups, depending upon habitat / environmental factors, seasons and stage of maturity. Comparing these findings with our results, it is to mention here that most of the specimens of selected fishes predated more on mosquito immature when supplemented with alternative food.

Fragments of aquatic macrophytes have not been recorded in the stomach contents of Anabas testudineus and M. vittatus (Wijeyaratne and Perera, 2001) while in the present study both algae and weeds have been collected from the stomach of these fishes. The major food items of $R$. daniconius was found to be detritus (Wijeyaratne and Perera, 2001) while in Anabas testudineus, the major food item was animal matter, contributing more than $70 \%$ of the diet. In their findings, in the fish M. vittatus, the detritus / animal matter was main food item depending upon localities. The findings of present study are just contrary to this. As per results of Wijeyaratne and Perera, (2001) A. testudineus, although omnivore, fed mainly on animal matter but in our study worms are recorded as the most preferred diet of this fish. Jauhari et al. (1996) worked out the larvivorous potential of 9 indigenous species of fish based on the food specimens in their gastrointestinal contents and by providing different stages of Anopheles culicifacies larvae. As per their studies the food spectrum in the gut contents includes crustaceans, insects, algae, diatoms, detritus, digested matter and others. The findings of the present study resemble slightly considering the kind of food present but differ from them in having weeds, tadepole fish, mosquito larvae/pupae, gastropods and worms in the gut contents.

Kumar et al. (2008) observed that larval removal rate decreases with increasing larval size and instar stage. This is in accordance to our studies as the remains of $2^{\text {nd }}$ and 
$3^{\text {rd }}$ larval instar were obtained in the stomach contents in all the 8 selected fishes. With regard to the assumption that the predatory potential of larvivorous fish can be affected by the presence of alternative preys, the present findings are close to Manna et al. (2008). In the findings of Rojas et al. (2005) in respect of digestive contents of fishes and their implications as bioregulators of mosquito larvae, all the selected fishes preferred larvae and pupae of mosquitoes combined with other food. This is close to our studies; the only difference is with the species of fish. There is also a bit resemblance of the present study with the fingdings of Jacob and Nair (2006).

The possible explanation about the preference diet of larvivorous fish follows the views of Windell (1967) who found that in a fish the food intake is dependent on the gastric evacuation. Further, the soft food organisms such as worms and dipterans larvae are found to be digested more rapidly than the heavily chitinised forms (Nikolsky, 1963). Besides this, Oligochaete worms have been reported to be highly nutritive (Galinat, 1960) and easily digested by fish (Mann, 1935).

Conclusively, it is recommended that it is a must to observe an effective bioregulatory activity of fishes under natural condition to select them as biocontrol agent.

\section{ACKNOWLEDGEMENTS}

Financial assistance rendered to one of us (NPD) from DST, New Delhi in the form of WOS-B fellowship is highly acknowledged. Thanks are also due to the Principal D.A.V.(P.G.) College, Dehradun for providing adequate laboratory facilities and to the State Fisheries Department, Govt. of Manipur, Imphal for cooperation.

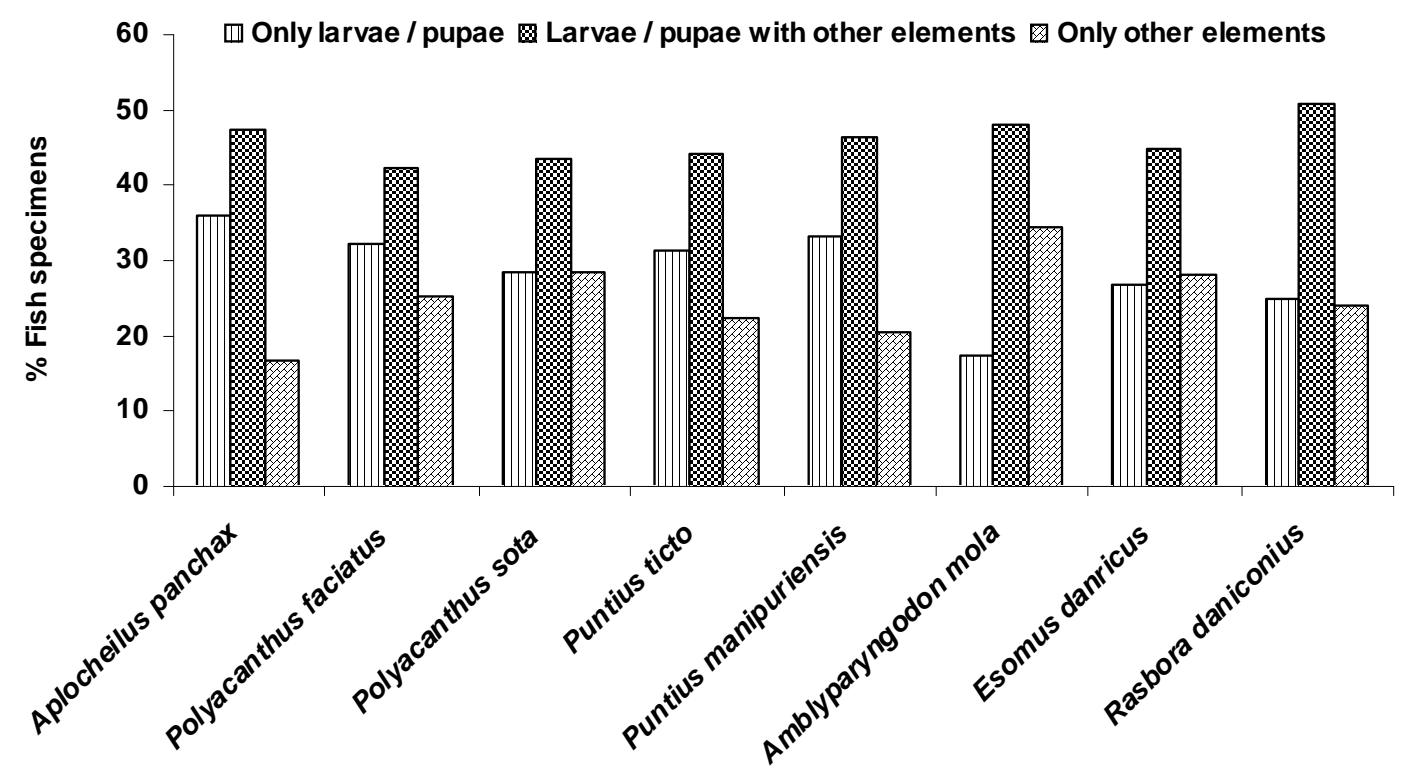

Fig.1. A comparison of gastro-intestinal contents of selected fishes with larvae/pupae of mosquitoes.

\section{REFERENCES}

Bence, J.R. (1988). Indirect effects and biological control of mosquitoes by mosquito fish. J. Appl. Ecol., 25(2): 505-21.

Chandra, G., Bhattacharjee, I., Chatterjee, S.N. and Ghosh, A. (2008). Mosquito control by larvivorous fish. Indian J. Med. Res., 127, 13-27.

Das, M.K. and Prasad, R.N. (1991). Evaluation of mosquito fish Gambusia affinis in the control of mosquito breeding in rice fields. Indian J. Med. Res., 72: 214-217.

Fletcher, M.A., Teklchaimanot, A., Yemane, G., Kassahum, A., Kidane, G. and Beyene, Y. (1993). Prospects for the use of larvivorous fish for malaria control in Ethiopia: search for indigenous species and evaluation of their feeding capacity for mosquito larvae. J. Trop. Med. Hyg., 96(1):12-21.

Galinat, A. (1960). Experimental studies on the utilization of natural food by young crucian (Carassius L.) and tench (Tinca tinca L.). Pol. Arch. Hydrobiol., 8 :129-152.
Gerberich, J.B. and Laird, M. (1968). A bibliography of papers relating to the control of mosquitoes by the use of fish. An annotated bibliography for the years 1901-1966. FAO Fisheries Tec. Paper, 75: 70.

Ghosh, A., Bhattacharjee, I. and Chandra, G. (2006). Biocontrol efficacy by Orechromis niloticus niloticus. J. Appl. Zool. Res., 17:114-116.

Gratz, N.G. and Pal, R. (1988). Malaria vector control: larviciding. In: Wernsdorfer, W.H., and I. McGregor, editor. Malaria: principles and practice of malariology. Edinburgh, UK: Churchill Livingstone, pp.1213-26.

Haq, S. and Yadav, R.S. (2003). Developing larvivorous fish network for mosquito control in urban areas: A case study. ICMR Bull., 33: 69-73.

Hurst, T.P., Brown, M.D. and Kay, B.H. (2004). Laboratory evaluation of the predation efficacy of native Australian fish on Culex annulirostris (Diptera: Culicidae). J. Amer. Mosq. Cont. Assoc., 20: 286-291. 
Jacob, S.S. and Nair, N.B. (2006). Food and feeding habits of the larvivorous fish Aplocheilus lineatus (Cuv. \& Val.) in its natural habitat. J. Fish Biology, 20(3): 329-339.

Jauhari, R.K. Saxena, R.M., Srivastava, J.K. and Mahesh, R.K. (1996). Larvivorous potential of some indigenous fishes of Doon valley with special reference to their efficacy in control of Anophelines. J. Parasit. Appl. Anim. Biol., 5(1): 49-55.

Kumar, R., Muhid, P., Dahms, H.U., Tseng, L.C. and Hwang, J.S. (2008). Potential of three aquatic predators to control mosquitoes in the presence of alternative prey: a comparative experimental assessment. Marine and Freshwater Research, 59(9): 817-835.

Lee, D.K. (2000). Predation efficacy of the fish muddy loach, Misgurnus mizolepis, against Aedes and Culex mosquitoes laboratory and small rice plots. J. Amer. Mosq. Cont. Assoc., 16(3): 61-258

Mann, H. (1935): Untersuchubgen uber die Verdollung and Ausnutsung der Stickstoff-shustanz einiger Nahritiere durch Verschiedens Fische. Z. Fishche., 33 : 231-274.

Manna, B., Aditya, G. and Banerjee, S. (2008). Vulnerability of the mosquito larvae to the guppies (Poecilia reticulata) in the presence of alternative preys. J. Vector Borne Dis., 45: 200206.

Nelson, S.M. and Keenan, L.C. (1992). Use of an indigenous fish species, Fundulus zebrinus, in a mosquito abatement program: a field comparison with the mosquito fish, Gambusia affinis. J. Amer. Mosq. Cont. Assoc., 8(3): 301304.

Nikolsky, G.V. (1963). The ecology of fishes (London and New York: Academic Press) pp.352.
Reddy, S.R. and Shakuntala, K. (1979). Comparative studies on the food intake, growth and food conversation of two larvivorous fishes. Proc. Indian Acad. Sci., 88(1): 425-432.

Rehage, J.S., Barnetti, B.K. and Sih, A. (2005). Foraging behaviour and invasiveness: do invasive Gambusia exhibit higher feeding rates and broader diets than their noninvasive relatives? Ecol. Freshwater Fishes, 14: 352-360.

Rojas, J.E., Soca, L.A and Garcia, G.I. (2005). Content of the digestive tract of 4 authoctonous species of fishes and their implications as bioregulators of mosquito larvae in Venezuela. Rev. Cubana Med. Trop., 57(3): 196-200.

Sharma, V.P. and Ghosh, A.(1989). Larvivorous fishes of inland ecosystems In: Proceedings of the MRC-CICFRI Workshop; 1989 Sep 27-28; New Delhi, (Eds. Drs V.P. Sharma and A. Ghosh) : Malaria research Centre (ICMR); Delhi; (1989) pp1-224.

Torrente, A., Rojas, W., Duran, A., Kano, T. and Orduz, S. (1993). Fish species from mosquitoes breeding ponds in northwestern Colombia: evaluation of feeding habits and distribution. Mem. Inst. Oswaldo Cruz., 88: 625-627.

Vishwanath, W., Lakra, W.S. and Sarkar, U.K. (2007). Fishes of North East India. National Bureau of Fish Genetic Resources (ICAR). pp.1- 264.

Wijeyaratne, M.J.S. and Perera, W.M.D.S.K. (2001). Trophic interrelationships among the exotic and indigenous fish cooccurring in some reservoirs in Sri Lanka. Asian Fisheries Sci., $14: 333-342$.

Windell, J.T. (1967). Rates of digestion in fishes; in the biological basis of freshwater fish production ed. S D Gerking, (London: Blackwell Sci. Pub.) pp. 151-173. 